\title{
Movement of blue shark, Prionace glauca, in the north-east Atlantic based on mark - recapture data
}

\author{
Nuno Queiroz*ף, Fernando P. Lima*, Anabela Maia ${ }^{\ddagger}$, Pedro A. Ribeiro*j, João P. Correia ${ }^{\S}$ \\ and António M. Santos* ${ }^{\dagger}$ \\ *CIBIO, Centro de Investigação em Biodiversidade e Recursos Genéticos, Campus Agrário de Vairão, 4485-661 Vairão, Portugal. \\ ${ }^{\dagger}$ Departamento de Zoologia-Antropologia, Faculdade de Ciências da Universidade do Porto, 4099-002 Porto, Portugal. \\ ${ }^{\ddagger}$ Universidade de Lisboa, Faculdade de Ciências, Instituto de Oceanografia, Campo Grande, 1749-016 Lisboa, Portugal. \\ ${ }^{\int_{S}}$ School of Biological Sciences, University of Southampton, Basset Crescent East, Southampton, SO16 7PX, UK. \\ ${ }^{\S}$ Oceanário de Lisboa, SA, Esplanada D. Carlos I-Doca dos Olivais, 1990-005 Lisboa, Portugal. \\ 'Corresponding author, e-mail: nuno.queiroz@apece.pt
}

\begin{abstract}
A shark tagging programme along the Portuguese coast was initiated in 2001 in collaboration with the National Marine Fisheries Service. From a total of 168 blue sharks (Prionace glauca) tagged, 34 sharks were recaptured (20\% return rate) providing important information on this species' movement patterns for the area. A total of 28 sharks travelled less than $1000 \mathrm{~km}$ while at liberty for time periods ranging from 22 to 1294 days. The remaining fish travelled long distances to north-west Africa, central Atlantic and the Bay of Biscay. Only one shark made a transatlantic migration, being recaptured $3187 \mathrm{~km}$ from the tagging site. North-south movements seem to be related to seasonal sea-surface temperature variation in the north-east Atlantic. Seasonal segregation of different life stages also occurs.
\end{abstract}

\section{INTRODUCTION}

The blue shark, Prionace glauca (Linnaeus, 1758), is probably the widest ranging chondrichthyian (Compagno, 1984) inhabiting oceanic and circumglobal waters both in temperate and tropical seas (Stevens, 1990). It is found over the entire mid-Atlantic, ranging from Newfoundland to Argentina in the west and from Norway to South Africa in the east (Compagno, 1984).

The study of sharks in their natural environment poses several difficulties due to their size, free-ranging behaviour, and the fact that they live in a relatively inaccessible and concealing environment (Sundström et al., 2001). Nonetheless, scientific tagging of sharks and other pelagic fish has been an area of considerable research. These studies have generally been hampered by a variety of factors, such as low tag returns, tagging induced mortality, incorrect recording of tag or recapture data (Kohler \& Turner, 2001), dependence upon fishermen to return tags (Holden \& Horrod, 1979), fishing pressure and tag shedding (Stevens, 1976; Graves et al., 2002). Furthermore, mark-recapture experiments provide no information concerning the extent and direction of movement during the intervening period at liberty (Bolle et al., 2005).

Despite their limitations, tagging programmes have provided valuable information on a wide variety of aspects of fish biology, including age validation and growth parameters (Pratt \& Casey, 1983; Cailliet et al., 1992; Shackell et al., 1997; Hearn \& Polacheck, 2003) as well as pelagic species' movements (Thorson, 1971; Holden \& Horrod, 1979; Holland et al., 2001). Data gathered in such programmes can also be used to analyse the distribution of sizes and sex ratios, indices of relative abundance, multinational fisheries management and stock structure (Kohler et al., 2002). Blue shark tagging studies developed in the Atlantic Ocean have been successful in collecting information on short- and long-term movements and migrations, growth rate, reproductive behaviour and in identifying mating and nursery areas (Stevens, 1976; Casey, 1985).

The present study aims to describe the movement patterns of blue sharks tagged off the Portuguese coast and investigate the influence of bottom relief features and sea-surface temperature (SST) in these patterns and in the species' distribution in the north-east Atlantic.

\section{MATERIALS AND METHODS}

A shark tagging programme along the Portuguese coast was initiated in 2001 in cooperation with the National Marine Fisheries Service (NMFS). Blue sharks were caught on rod and line and marked by sport fishermen using charter boats, in three main areas of the Portuguese coast (Figure 1). Fishermen were trained for tagging according to the procedures of the NMFS Cooperative Shark Tagging Programme. Dart tags were implanted in the dorsal musculature near the base of the first dorsal fin. According to Casey (1985), this type of tag has the advantage of containing detailed return instructions, being visible and easily applied with simple and inexpensive equipment. Fishermen were asked to measure shark fork length (FL) (over-the-body) or, failing this, to estimate their length visually. Whenever shark FL was unavailable it was calculated from reported total length using the equations provided by Kohler et al. (1996).

All recaptures were made by commercial surface longline vessels targeting swordfish (Xiphias gladius Linnaeus, 


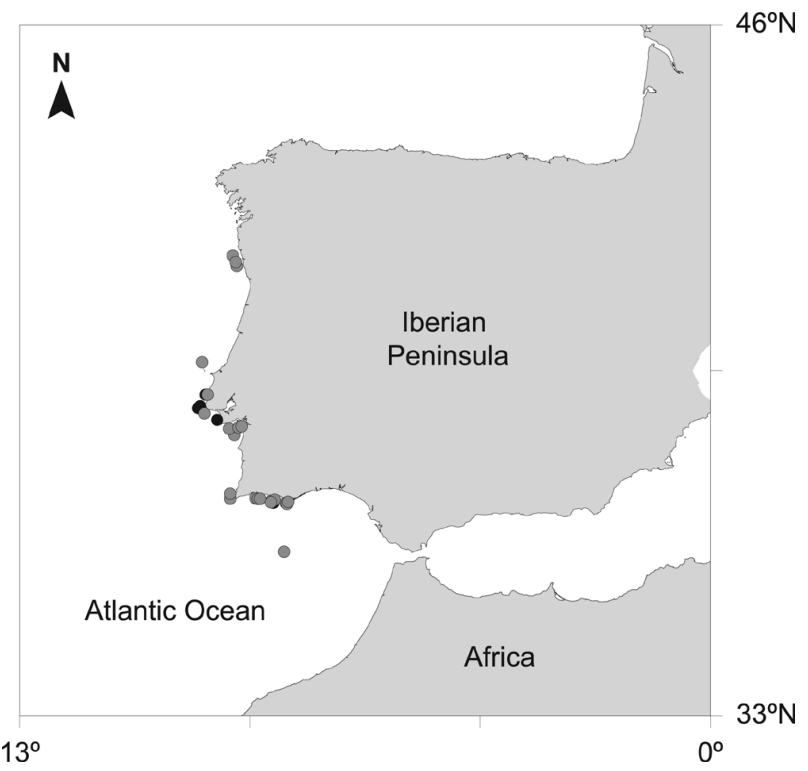

Figure 1. Locations of tagged sharks off the Portuguese coast; black circles are male positions and grey circles are female positions.
1758). Because size at recapture, when available, was always estimated roughly (in many cases it was only an estimate of dressed weight), FL at recapture was computed using the growth curves provided by Skomal \& Natanson (2003) and time at liberty.

Capture and recapture locations were plotted on bottom topography and SST images with locations geo-referenced using the GRASS Geographical Information System (GRASS Development Team, 2005). Bathymetry data were obtained using the 2-min gridded global relief database (http://www.ngdc.noaa.gov/) from the Geophysical Data System (GEODAS) National Geophysical Data Center (NGDC). Minimum distance between capture and recapture sites was calculated avoiding land using the GRASS GIS shortest-path module (v.net.path), thus providing a better estimate of the travelled distance.

Sea-surface temperature (MODIS/Terra) data were obtained through the online PO.DAAC Ocean ESIP Tool (POET) (http://poet.jpl.nasa.gov/) at the Physical Oceanography Distributed Active Archive Center (PO.DAAG), NASA Jet Propulsion Laboratory. Seasons were defined as winter (December to February), spring

Table 1. Release and recapture details for tagged blue sharks.

\begin{tabular}{|c|c|c|c|c|c|c|c|c|c|c|}
\hline \multicolumn{5}{|c|}{ Capture } & \multicolumn{6}{|c|}{ Recapture } \\
\hline Lat. N & Long. W & Date & Sex & $\mathrm{FL}(\mathrm{cm})$ & Lat. N & Long. W & Date & $\mathrm{FL}(\mathrm{cm})$ & DL & $\mathrm{TD}(\mathrm{Km})$ \\
\hline $36^{\circ} 53^{\prime}$ & $08^{\circ} 10^{\prime}$ & 03-Apr-01 & $\mathrm{F}$ & $147^{*}$ & $37^{\circ} 02^{\prime}$ & $07^{\circ} 30^{\prime}$ & 24-Мay-01 & $150 *$ & 51 & 62 \\
\hline $36^{\circ} 55^{\prime}$ & $08^{\circ} 08^{\prime}$ & 20-Apr-01 & $\mathrm{F}$ & 110 & $37^{\circ} 00^{\prime}$ & $09^{\circ} 06^{\prime}$ & 24-Мау-01 & 112 & 34 & 89 \\
\hline $36^{\circ} 58^{\prime}$ & $08^{\circ} 43^{\prime}$ & 26-Jun-01 & $\mathrm{F}$ & 116 & $36^{\circ} 56^{\prime}$ & $08^{\circ} 29^{\prime}$ & 20-Jul-01 & 118 & 24 & 12 \\
\hline $36^{\circ} 58^{\prime}$ & $08^{\circ} 43^{\prime}$ & 28-Jun-01 & $\mathrm{M}$ & 120 & $36^{\circ} 56^{\prime}$ & $08^{\circ} 29^{\prime}$ & 20-Jul-01 & 122 & 22 & 12 \\
\hline $36^{\circ} 57^{\prime}$ & $08^{\circ} 26^{\prime}$ & 07-Jun-01 & $\mathrm{M}$ & 125 & $39^{\circ} 30^{\prime}$ & $10^{\circ} 20^{\prime}$ & 26-Oct-01 & 136 & 141 & 360 \\
\hline $37^{\circ} 09^{\prime}$ & $09^{\circ} 10^{\prime}$ & 07-Мay-01 & M & 105 & $38^{\circ} 17^{\prime}$ & $09^{\circ} 60^{\prime}$ & 18-Sep-01 & 117 & 134 & 146 \\
\hline $36^{\circ} 58^{\prime}$ & $08^{\circ} 43^{\prime}$ & 30-Aug-01 & $\mathrm{F}$ & 134 & $37^{\circ} 10^{\prime}$ & $12^{\circ} 30^{\prime}$ & 31-Oct-01 & 138 & 62 & 349 \\
\hline $36^{\circ} 58^{\prime}$ & $08^{\circ} 43^{\prime}$ & 05-Aug-01 & $\mathrm{F}$ & 98 & $41^{\circ} 30^{\prime}$ & $09^{\circ} 40^{\prime}$ & 06-Sep-01 & 100 & 32 & 553 \\
\hline $36^{\circ} 54^{\prime}$ & $08^{\circ} 11^{\prime}$ & $17-A p r-01$ & $\mathrm{~F}$ & 120 & $43^{\circ} 52^{\prime}$ & $03^{\circ} 35^{\prime}$ & $01-$ Sep-01 & 129 & 137 & 1256 \\
\hline $36^{\circ} 58^{\prime}$ & $08^{\circ} 43^{\prime}$ & 25-Jun-01 & $\mathrm{F}$ & 110 & $38^{\circ} 15^{\prime}$ & $08^{\circ} 53^{\prime}$ & 05-Nov-01 & 119 & 133 & 187 \\
\hline $37^{\circ} 09^{\prime}$ & $09^{\circ} 10^{\prime}$ & 23-Мау-01 & $\mathrm{M}$ & 108 & $38^{\circ} 22^{\prime}$ & $08^{\circ} 56^{\prime}$ & 05-Nov-01 & 122 & 166 & 182 \\
\hline $36^{\circ} 58^{\prime}$ & $08^{\circ} 43^{\prime}$ & 17-Jul-01 & $\mathrm{F}$ & 118 & $37^{\circ} 40^{\prime}$ & $10^{\circ} 20^{\prime}$ & 20-Nov-01 & 126 & 126 & 180 \\
\hline $36^{\circ} 58^{\prime}$ & $08^{\circ} 43^{\prime}$ & 01-Sep-01 & $\mathrm{M}$ & 99 & $36^{\circ} 40^{\prime}$ & $08^{\circ} 01^{\prime}$ & $26-N o v-01$ & 106 & 86 & 63 \\
\hline $37^{\circ} 01^{\prime}$ & $08^{\circ} 34^{\prime}$ & 27-Jul-01 & $\mathrm{F}$ & 110 & $34^{\circ} 00^{\prime}$ & $07^{\circ} 53^{\prime}$ & 15-Jan-02 & 122 & 172 & 341 \\
\hline $37^{\circ} 01^{\prime}$ & $08^{\circ} 34^{\prime}$ & 24-Jul-01 & $\mathrm{F}$ & 67 & $39^{\circ} 20^{\prime}$ & $14^{\circ} 00^{\prime}$ & 20-Jan-02 & 82 & 180 & 551 \\
\hline $37^{\circ} 00^{\prime}$ & $08^{\circ} 35^{\prime}$ & 31-Jul-01 & $\mathrm{F}$ & 61 & $37^{\circ} 05^{\prime}$ & $09^{\circ} 06^{\prime}$ & 10-Apr-02 & 83 & 253 & 57 \\
\hline $36^{\circ} 58^{\prime}$ & $08^{\circ} 43^{\prime}$ & 02-Nov-01 & $\mathrm{F}$ & 86 & $39^{\circ} 00^{\prime}$ & $18^{\circ} 00^{\prime}$ & 25-Маy-02 & 102 & 204 & 847 \\
\hline $35^{\circ} 56^{\prime}$ & $08^{\circ} 09^{\prime}$ & 30-Apr-01 & $\mathrm{F}$ & 108 & $47^{\circ} 40^{\prime}$ & $08^{\circ} 15^{\prime}$ & 26-Jul-02 & 138 & 452 & 1344 \\
\hline $36^{\circ} 54^{\prime}$ & $08^{\circ} 10^{\prime}$ & 24-Apr-01 & $\mathrm{F}$ & 108 & $46^{\circ} 50^{\prime}$ & $03^{\circ} 10^{\prime}$ & 23-Aug-02 & 140 & 486 & 1407 \\
\hline $36^{\circ} 54^{\prime}$ & $08^{\circ} 25^{\prime}$ & 06-Мay-02 & M & 110 & $35^{\circ} 59^{\prime}$ & $08^{\circ} 34^{\prime}$ & 08-Aug-02 & 118 & 94 & 103 \\
\hline $36^{\circ} 58^{\prime}$ & $08^{\circ} 43^{\prime}$ & 24-Oct-01 & $\mathrm{M}$ & 85 & $43^{\circ} 10^{\prime}$ & $09^{\circ} 45^{\prime}$ & 20-Aug-02 & 112 & 300 & 727 \\
\hline $36^{\circ} 54^{\prime}$ & $08^{\circ} 25^{\prime}$ & 12-Jun-02 & $\mathrm{M}$ & 130 & $36^{\circ} 35^{\prime}$ & $11^{\circ} 40^{\prime}$ & 27-Jan-03 & 146 & 229 & 292 \\
\hline $36^{\circ} 54^{\prime}$ & $08^{\circ} 25^{\prime}$ & 22-Jun-02 & $\mathrm{M}$ & 125 & $36^{\circ} 40^{\prime}$ & $14^{\circ} 15^{\prime}$ & 27-Jan-03 & 141 & 219 & 521 \\
\hline $36^{\circ} 58^{\prime}$ & $08^{\circ} 43^{\prime}$ & 16-Aug-01 & $\mathrm{F}$ & 80 & $42^{\circ} 45^{\prime}$ & $17^{\circ} 24^{\prime}$ & 15-Dec-02 & 117 & 486 & 991 \\
\hline $36^{\circ} 58^{\prime}$ & $08^{\circ} 43^{\prime}$ & 04-Aug-01 & $\mathrm{M}$ & 67 & $39^{\circ} 00^{\prime}$ & $45^{\circ} 00^{\prime}$ & 01-May-03 & 125 & 635 & 3187 \\
\hline $38^{\circ} 23^{\prime}$ & $09^{\circ} 03^{\prime}$ & 14-Jun-03 & $\mathrm{F}$ & 93 & $42^{\circ} 10^{\prime}$ & $15^{\circ} 50^{\prime}$ & 27-Aug-03 & 99 & 74 & 717 \\
\hline $36^{\circ} 53^{\prime}$ & $08^{\circ} 13^{\prime}$ & 03-Oct-03 & $\mathrm{M}$ & 100 & $36^{\circ} 30^{\prime}$ & $11^{\circ} 20^{\prime}$ & 28-Apr-04 & 118 & 208 & 281 \\
\hline $36^{\circ} 58^{\prime}$ & $08^{\circ} 43^{\prime}$ & 04-Sep-02 & $\mathrm{F}$ & 120 & $40^{\circ} 30^{\prime}$ & $22^{\circ} 30^{\prime}$ & 04-Jun-04 & 159 & 639 & 1261 \\
\hline $38^{\circ} 43^{\prime}$ & $09^{\circ} 44^{\prime}$ & 17-Oct-03 & $\mathrm{M}$ & 82 & $41^{\circ} 28^{\prime}$ & $11^{\circ} 00^{\prime}$ & 20-Aug-04 & 110 & 308 & 329 \\
\hline $36^{\circ} 54^{\prime}$ & $08^{\circ} 25^{\prime}$ & 06-Jan-02 & $\mathrm{M}$ & 135 & $32^{\circ} 24^{\prime}$ & $9^{\circ} 40^{\prime}$ & 01-Sep-04 & $191 * *$ & 969 & 514 \\
\hline $36^{\circ} 54^{\prime}$ & $08^{\circ} 25^{\prime}$ & 10-Jul-02 & $\mathrm{F}$ & 130 & $22^{\circ} 11^{\prime}$ & $21^{\circ} 12^{\prime}$ & 12-Sep-04 & $175^{*}$ & 795 & 2049 \\
\hline $36^{\circ} 54^{\prime}$ & $08^{\circ} 25^{\prime}$ & 13-Oct-02 & $\mathrm{F}$ & 96 & $35^{\circ} 30^{\prime}$ & $11^{\circ} 30^{\prime}$ & 10-Aug-04 & 142 & 667 & 318 \\
\hline $36^{\circ} 54^{\prime}$ & $08^{\circ} 04^{\prime}$ & 11-Apr-01 & $\mathrm{F}$ & 113 & $36^{\circ} 45^{\prime}$ & $14^{\circ} 10^{\prime}$ & 26-Oct-04 & $186 * *$ & 1294 & 544 \\
\hline $36^{\circ} 57^{\prime}$ & $08^{\circ} 26^{\prime}$ & 12-Jun-01 & $\mathrm{F}$ & 110 & $30^{\circ} 15^{\prime}$ & $13^{\circ} 20^{\prime}$ & 13-Jan-04 & $167 *$ & 945 & 873 \\
\hline
\end{tabular}

Lat., latitude; Long., longitude; FL, fork length; DL, days at liberty; TD, travelled distance. FL at recapture was computed using the growth curves provided by Skomal \& Natanson (2003) and time at liberty; *, sub-adult females; **, adult sharks. 


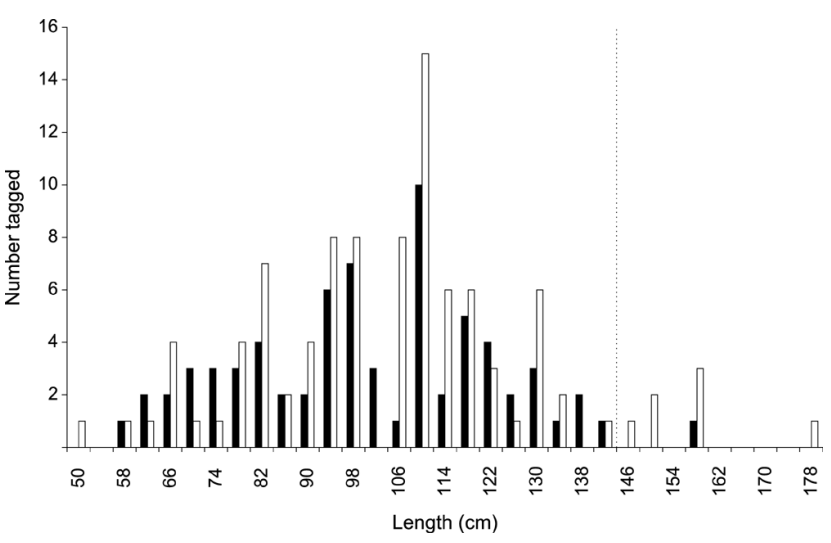

Figure 2. Length-frequency distributions of tagged blue sharks; black bars are males and white bars are females. Size at which females reach a sub-adult stage is depicted by a dotted line.

(March to May), summer (June to August) and autumn (September to November). Seasonal SST plots were calculated as 4-y seasonal averages comprising data from December 2000 to November 2004.

A $\chi^{2}$-test was used to compare length distribution of recaptured fish (at tagging) and length distribution of all captured fish, in order to identify any bias in the recaptures. Pearson's correlation coefficients were estimated between distance travelled and time at liberty or size of fish (at recapture). A $t$-test was used to test for differences in average travelled distance between sexes.

\section{RESULTS}

Between April 2001 and September 2004, a total of 168 blue sharks was tagged off the Portuguese coast. The length-frequency distribution of captured sharks is shown in Figure 2. The average FL was $105 \mathrm{~cm}$ with a mode at approximately $110 \mathrm{~cm}$. About 58\% ( N=98) of the tagged sharks were females, ranging in size from 51 to $180 \mathrm{~cm}$ FL. Males $(\mathrm{N}=70)$ were on average smaller, ranging from about 60 to $160 \mathrm{~cm}$ FL. Of the tagged sharks, all males and $93 \%$ of the females were immature, while $7 \%$ were passing through a sub-adult phase as defined by Pratt (1979).

During this study, 34 tags $(20 \%)$ had been recovered. Details of shark length, position and date of capture and recapture are given in Table 1. Length distribution of recaptured fish (at tagging) was not statistically different from length distribution of all captured sharks $\left(\chi^{2}=21.849\right.$, $\mathrm{df}=26, P=0.696)$ suggesting that recapture was not conditioned by size at tagging.

Minimum travelled distance is depicted in Figure 3. Time at liberty and travelled distance were positively correlated, although this correlation was small $(r=0.469$, $P=0.005)$. Of the 34 recaptured sharks, 28 travelled less than $1000 \mathrm{~km}$, and were caught either in the same year or up to three and half years later. Of the remaining individuals, five females travelled long distances (between 1256 and $2049 \mathrm{~km}$ ) and were caught off north-west Africa, in the central Atlantic and in the Bay of Biscay. Time at liberty for these fish ranged between 137 and $795 \mathrm{~d}$.

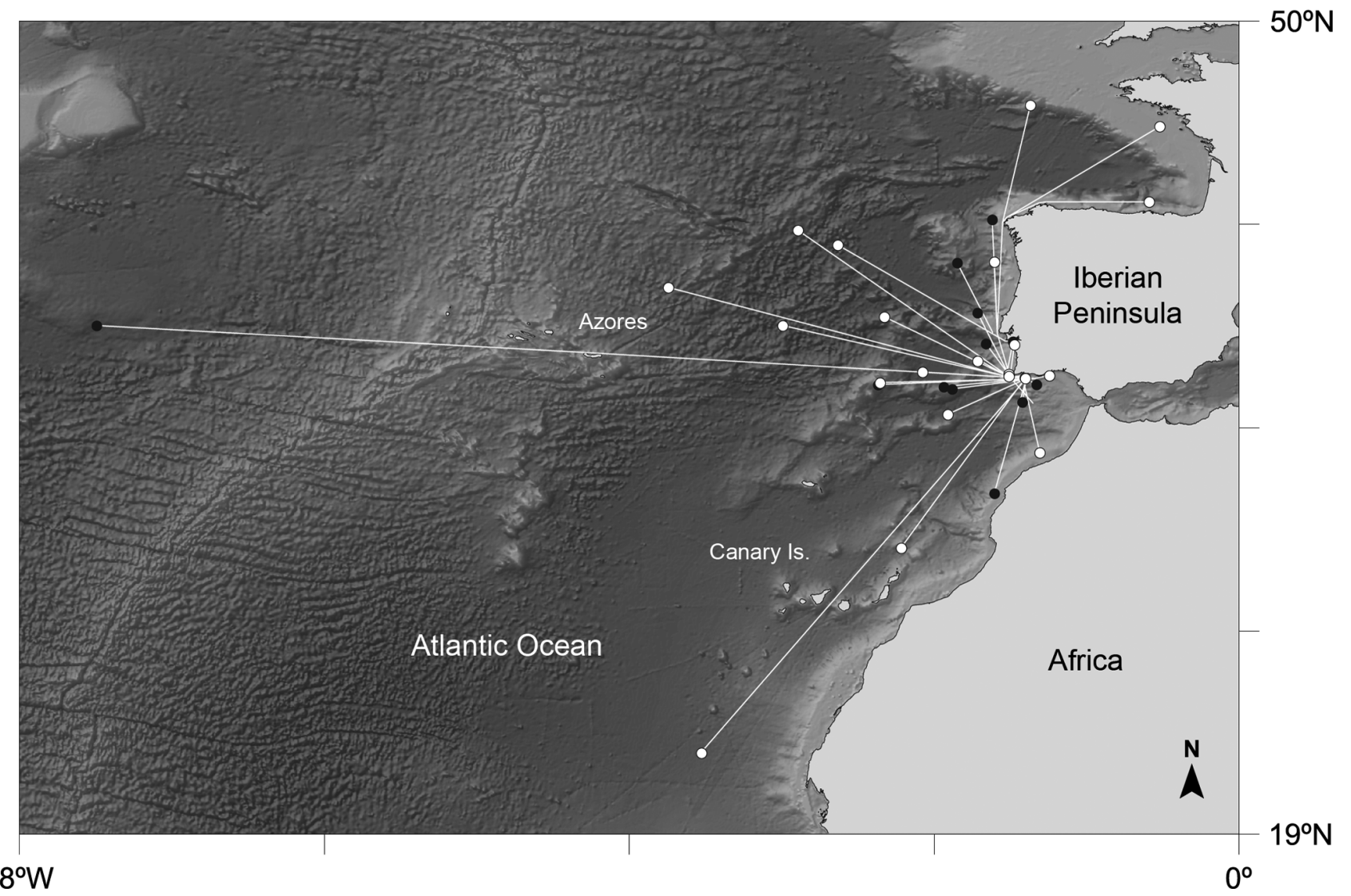

Figure 3. Travel paths and recapture positions for blue sharks; black circles are male recapture positions and white circles are female recapture positions. 

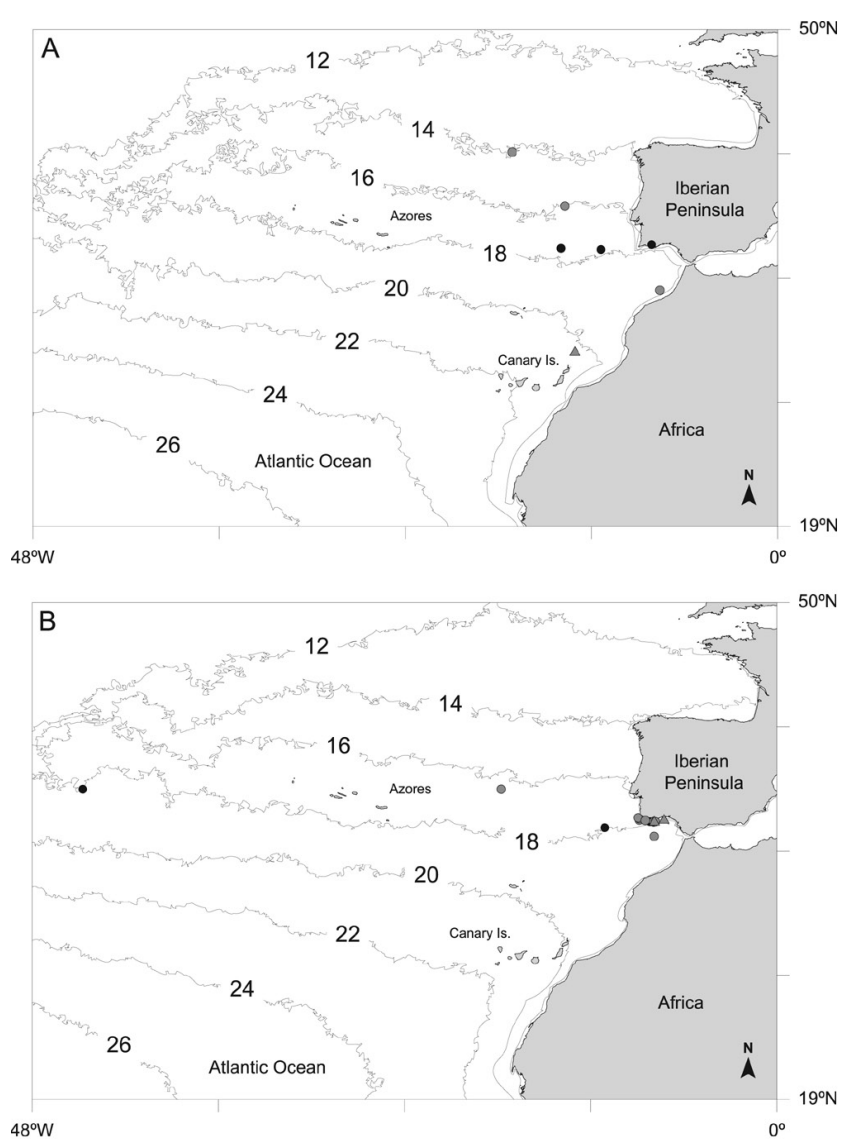
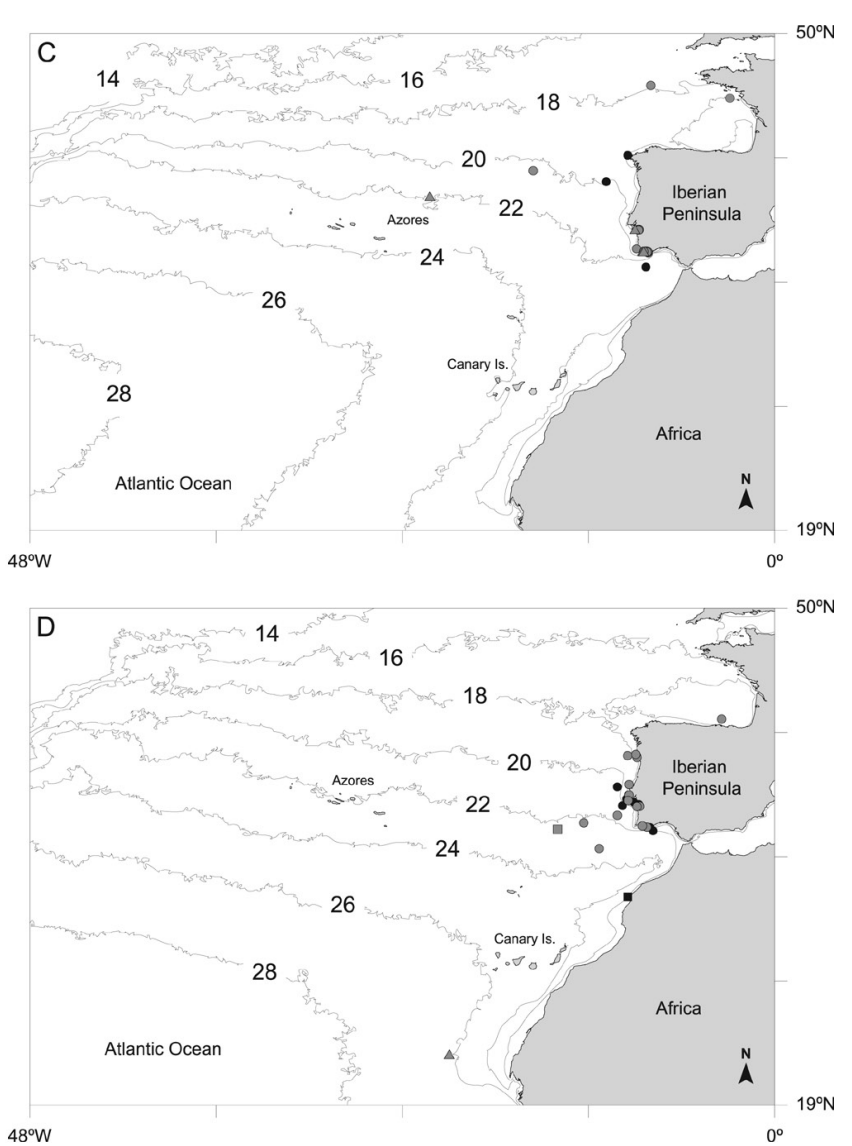

Figure 4. Positions of captured/recaptured blue sharks in relation to sea-surface temperature (SST) features. Plots represent 4-year seasonal averages, from December 2000 to November 2004. (A) Winter (December-February); (B) spring (March-May); (C) summer (June-August); (D) autumn (September-November). Black symbols are male capture/recapture positions; grey symbols are female capture/recapture positions; $\bigcirc$, immature sharks; $\triangle$, sub-adult females; $\square$, adult sharks.

According to the classification provided by Casey (1985), one male shark $(67 \mathrm{~cm}$ FL at tagging) made a transatlantic migration travelling $3187 \mathrm{~km}$ in $635 \mathrm{~d}$, an average of $5.02 \mathrm{~km} \mathrm{~d}^{-1}$.

No correlation was found between size (FL at recapture) and travelled distance $(r=0.250, P=0.154)$. Average travelled distance was not statistically significant between sexes $(t=0.267, \mathrm{df}=21, P=0.792)$. The rate of movement ranged from 0.23 to $17.29 \mathrm{kmd}^{-1}$, with an average of $2.76 \mathrm{~km} \mathrm{~d}^{-1}$.

Overall, 32 sharks were recaptured in the vicinity of areas with high bottom relief, such as seamounts, canyons or the continental shelf slope (Figure 3). There were two exceptions, one shark recaptured south of the Canary Islands $\left(22^{\circ} 11^{\prime} \mathrm{N} 21^{\circ} 12^{\prime} \mathrm{W}\right)$ and another in the Bay of Biscay, west of Les Sables-d'Olonne $\left(46^{\circ} 50^{\prime} \mathrm{N} 03^{\circ} 10^{\prime} \mathrm{W}\right)$.

In the winter and spring months blue sharks were found in a SST range of $14-22^{\circ} \mathrm{C}$ and between $30^{\circ}-43^{\circ} \mathrm{N}$ (Figure 4A,B). During summer and autumn, sharks were captured as far north as $48^{\circ} \mathrm{N}$ and the SST ranged from $16^{\circ} \mathrm{C}$ to $28^{\circ} \mathrm{C}$ (Figure 4C,D). Overall, $82 \%$ of the sharks were found in a SST range from $15.5^{\circ} \mathrm{C}$ to $20^{\circ} \mathrm{C}$.

During winter and autumn months (Figure 4A,D), all immature males and females were found off the African and the Iberian Peninsula coasts. One mature female was found in offshore waters off the south-west coast of Portugal. One mature male and two sub-adult females were spotted off the African coast. In the spring and summer months no mature sharks were captured but subadult females were found both in southern and central Portugal and near the Azores archipelago.

\section{DISCUSSION}

The return rate of $20 \%$ obtained in this study is much higher than expected, since Stevens (1976) reported a return rate of $3.9 \%$ for sharks tagged in Portuguese waters and more than half of the 52 shark tagging studies reviewed by Kohler \& Turner (2001) reported return rates of less than $5 \%$. Some authors have suggested that small fish of modal length between 100 and $110 \mathrm{~cm}$ FL remain within a relatively confined area and do not take part in more extensive north-south migrations (Stevens, 1976; Kohler et al., 2002), thus increasing the probability of recapture. Although in the present study no positive correlation was found between size and travelled distance, $64 \%$ of the sharks that travelled less than $1000 \mathrm{~km}$ fall within the $100-110 \mathrm{~cm}$ FL size-range. The fact that in subsequent years blue sharks remain in or return to areas where they were tagged indicates that the Portuguese coast is a favoured area for this species in the north-east Atlantic.

Blue sharks tagged off Portugal between 1971 and 1981 (Stevens, 1976, 1990) were smaller than those observed in the present study, with reported sizes ranging from 35 to $134 \mathrm{~cm} \mathrm{FL}$ with a mode of $84 \mathrm{~cm} \mathrm{FL}(\mathrm{N}=332)$. The high percentage of immature individuals observed in these 
studies (including the present data) suggests that the north-eastern Atlantic population consists primarily of immature males and immature and sub-adult females with the sex ratio favouring the females (Kohler et al., 2002). Data from an ongoing sampling programme (2003-2005) of commercial shark landings on the three main Portuguese docks confirms this, since 94\% of captured male sharks were immature and $95 \%$ of females were immature or sub-adults.

Blue sharks are common off the Portuguese coast throughout the year and no seasonal pattern of movement is evident. On the other hand, results confirm that blue sharks undertake north-south migrations in the northeast Atlantic (Clarke \& Stevens, 1974; Stevens, 1976; Casey, 1985; Stevens, 1990). One of the disadvantages of tagging programmes is the fact that most tag returns are made by commercial fishing vessels. Hence, the distribution of recaptures may reflect the commercial fleet's activity rather than the true extent of fish migration (Bolle et al., 2005). Nonetheless, the summer range expansion towards the north, previously described by Clarke \& Stevens (1974) and Stevens (1976) for south-west England, seems not to be related to any seasonal changes in the distribution of longline fishing fleet, and thus biased by recapture methods. Data for swordfish catch per unit effort (e.g. Mejuto et al., 1992, 2003, 2004) show that in the north-east Atlantic fishing activity is rather constant throughout the year.

Although the number of recaptured individuals was small $(\mathrm{N}=34)$ no difference was found between sexes in the average distance travelled. The single transatlantic migration observed in this study supports the fact that juveniles are also involved in long-range movements (Casey, 1985).

Longlines are usually set in the vicinity of bottom topography features such as seamounts (unpublished data). Consequently, it is not surprising that 32 of the 34 recaptured blue sharks were caught near areas of high bottom relief. Seamounts support unusually large populations of fish (Wilson \& Boehlert, 2004), including pelagic species (Sibert et al., 2000; Holland et al., 2001). Most likely, high-relief bottom structures serve as orientation points in the larger-scale movements of blue sharks, as is the case for other shark species (Klimley et al., 1988, 2002) and migratory pelagic fish (Holland et al., 1999; Sedberry \& Loefer, 2001).

Water temperature is known to influence the movements of the blue shark (Nakano, 1994) as well as other fish (Laurs et al., 1977; Lutcavage et al., 2000; Sims et al., 2000; Skomal et al., 2004). The northward summer migration to British and Irish waters (Stevens, 1976; Henderson et al., 2001) seems to be influenced by an increase in SST north of the Iberian Peninsula (see Figure 4C,D). The results from the present work confirm that the blue shark has a wide thermal tolerance, but prefers a much narrower temperature range (Sciarrotta \& Nelson, 1977; Carey \& Scharold, 1990).

We thank the NMFS staff, namely Nancy Kohler and Ruth Briggs, for providing the tags and recapture data and all the fishermen and scientific staff of the Portuguese Association for the Study and Conservation of Elasmobranchs (APECE - http:// www.apece.pt) who became involved in the ongoing shark tagging programme. We thank two anonymous referees for comments which contributed to the improvement of the manuscript. This work was funded by APECE.

\section{REFERENCES}

Bolle, L.J., Hunter, E., Rijnsdorp, A.D., Pastoors, M.A., Metcalfe, J.D. \& Reynolds, J.D., 2005. Do tagging experiments tell the truth? Using electronic tags to evaluate conventional tagging data. ICES Journal of Marine Science, 62, 236-246.

Cailliet, G.M., Mollet, H.F., Pittenger, G.G., Bedford, D.W. \& Natanson, L.J., 1992. Growth and demography of the Pacific angel shark (Squatina californica), based upon tag returns off California. Australian Fournal of Marine and Freshwater Research, 43, 1313-1330.

Carey, F.G. \& Scharold, J.V., 1990. Movements of blue sharks (Prionace glauca) in depth and course. Marine Biology, 106, 329-342.

Casey, J.G., 1985. Transatlantic migrations of the blue shark; a case history of cooperative shark tagging. In Proceedings of the First World Angling Conference (ed. R.H. Stroud), pp. 253268. Capd'Agde, France: World Angling Resources and Challenges.

Clarke, M.R. \& Stevens, J.D., 1974. Cephalopods, blue sharks and migration. Fournal of the Marine Biological Association of the United Kingdom, 54, 949-957.

Compagno, L.J. V., 1984. FAO species catalogue. Vol. 4. Sharks of the world. An annotated and illustrated catalogue of shark species known to date. Part 2. Carcharhiniformes. FAO Fisheries Synopsis, 4, 251-655.

GRASS Development Team, 2005. Geographic resources analysis support system (GRASS). GNU General Public License, ITGirst, Trento, Italy.

Graves, J.E., Luckhurst, B.E. \& Prince, E.D., 2002. An evaluation of pop-up satellite tags for estimating postrelease survival of blue marlin (Makaira nigricans) from a recreational fishery. Fishery Bulletin, 100, 134-142.

Hearn, W.S. \& Polacheck, T., 2003. Estimating long-term growth-rate changes of southern bluefin tuna (Thunnus maccoyii) from two periods of tag-return data. Fishery Bulletin, 101, $58-74$.

Henderson, A.C., Flannery, K. \& Dunne, J., 2001. Observations on the biology and ecology of the blue shark in the north-east Atlantic. Journal of Fish Biology, 58, 1347-1358.

Holden, M.J. \& Horrod, R.G., 1979. The migrations of tope, Galeorhinus galeus (L), in the eastern North Atlantic as determined by tagging. Fournal du Conseil, 38, 314-317.

Holland, K.N., Kajiura, S.M., Itano, D.G. \& Sibert, J.R., 2001. Tagging techniques can elucidate the biology and exploitation of aggregated pelagic species. American Fisheries Society Symposium, 25, 211-218.

Holland, K.N., Kleiber, P. \& Kajiura, S.M., 1999. Different residence times of yellowfin tuna, Thunnus albacares, and bigeye tuna, T. obesus, found in mixed aggregations over a seamount. Fishery Bulletin, 97, 392-395.

Klimley, A.P., Beavers, S.C., Curtis, T.H. \& Jorgensen, S.J., 2002. Movements and swimming behavior of three species of sharks in La Jolla Canyon, California. Environmental Biology of Fishes, 63, 117-135.

Klimley, A.P., Butler, S.B., Nelson, D.R. \& Stull, A.T., 1988. Diel movements of scalloped hammerhead sharks, Shyrna lewini Griffith and Smith, to and from a seamount in the Gulf of California. Fournal of Fish Biology, 33, 751-761.

Kohler, N.E., Casey, J.G. \& Turner, P.A., 1996. Length-length and length-weight relationships for 13 shark species from the western North Atlantic. NOAA Technical Memorandum NMFS$\mathcal{N} E, 110,1-22$. 
Kohler, N.E. \& Turner, P.A., 2001. Shark tagging: a review of conventional methods and studies. Environmental Biology of Fishes, 60, 191-223.

Kohler, N.E., Turner, P.A., Hoey, J.J., Natanson, L.J. \& Briggs, R., 2002. Tag and recapture data for three pelagic shark species: blue shark (Prionace glauca), shortfin mako (Isurus oxyrinchus), and porbeagle (Lamna nasus) in the North Atlantic Ocean. Collective Volume of Scientific Papers. International Commission for the Conservation of Atlantic Tuna, 54, 1231-1260.

Laurs, R.M., Yuen, H.S.H. \& Johnson, J.H., 1977. Small-scale movements of albacore, Thunnus alalunga, in relation to ocean features as indicated by ultrasonic tracking and oceanographic sampling. Fishery Bulletin, 75, 347-355.

Lutcavage, M.E., Brill, R.W., Skomal, G.B., Chase, B.C., Goldstein, J.L. \& Tutein, J., 2000. Tracking adult North Atlantic bluefin tuna (Thunnus thynnus) in the northwestern Atlantic using ultrasonic telemetry. Marine Biology, 137, 347-358.

Mejuto, J., García-Cortés, B. \& Serna, J.M. de la, 2003. An overview of the activity of the Spanish surface longline fleet targeting swordfish (Xiphias gladius) during 2000, with special reference to the Atlantic Ocean. Collective Volume of Scientific Papers. International Commission for the Conservation of Atlantic Tuna, 55, 1485-1494.

Mejuto, J., García-Cortés, B., Serna, J.M. de la \& RamosCartelle, A., 2004. An overview of the activity of the Spanish surface longline fleet targeting swordfish (Xiphias gladius) during the year 2001, with special reference to the Atlantic Ocean. Collective Volume of Scientific Papers. International Commission for the Conservation of Atlantic Tuna, 56, 932-939.

Mejuto, J., Sánchez, P. \& Serna, J.M. de la, 1992. Nominal catch per unit of effort by length groups and areas of the longline spanish fleet targeting swordfish (Xiphias gladius) in the Atlantic, years 1988 to 1990 combined. Collective Volume of Scientific Papers. International Commission for the Conservation of Atlantic Tuna, 39, 615-625.

Nakano, H., 1994. Age, reproduction and migration of blue shark in the North Pacific Ocean. Bulletin of the National Research Institute of Far Seas Fisheries, 31, 141-234.

Pratt, H.L., 1979. Reproduction in the blue shark, Prionace glauca. Fishery Bulletin, 77, 445-470.

Pratt, H.L. \& Casey, J.G., 1983. Age and growth of the shortfin mako, Isurus oxyrinchus, using four methods. Canadian Fournal of Fisheries and Aquatic Sciences, 40, 1944-1957.
Sciarrotta, T.C. \& Nelson, D.R., 1977. Diel behavior of the blue shark, Prionace glauca, near Santa Catalina Island, California. Fishery Bulletin, 75, 519-528.

Sedberry, G.R. \& Loefer, J.K., 2001. Satellite telemetry tracking of swordfish, Xiphias gladius, off the eastern United States. Marine Biology, 139, 355-360.

Shackell, N.L., Stobo, W.T., Frank, K.T. \& Brickman, D., 1997. Growth of cod (Gadus morhua) estimated from mark-recapture programs on the Scotian Shelf and adjacent areas. ICES fournal of Marine Science, 54, 383-398.

Sibert, J.R., Holland, K.N. \& Itano, D.G., 2000. Exchange rates of yellowfin and bigeye tunas and fishery interaction between Cross seamount and near-shore FARDs in Hawaii. Aquatic Living Resources, 13, 225-232.

Sims, D.W., Southall, E.J., Quayle, V.A. \& Fox, A.M., 2000. Annual social behaviour of basking sharks associated with coastal front areas. Proceedings of the Royal Society, 267, 18971904.

Skomal, G.B. \& Natanson, L.J., 2003. Age and growth of the blue shark (Prionace glauca) in the North Atlantic Ocean. Fishery Bulletin, 101, 627-639.

Skomal, G.B., Wood, G. \& Caloyianis, N., 2004. Archival tagging of a basking shark, Cetorhinus maximus, in the western North Atlantic. Fournal of the Marine Biological Association of the United Kingdom, 84, 1-6.

Stevens, J.D., 1976. First results of shark tagging in the north-east Atlantic, 1972-1975. Fournal of the Marine Biological Association of the United Kingdom, 56, 929-937.

Stevens, J.D., 1990. Further results from a tagging study of pelagic sharks in the north-east Atlantic. Fournal of the Marine Biological Association of the United Kingdom, 70, 707-720.

Sundström, L.F. et al., 2001. Review of elasmobranch behavioral studies using ultrasonic telemetry with special reference to the lemon shark, Negaprion brevirostris, around Bimini Islands, Bahamas. Environmental Biology of Fishes, 60, 225-250.

Thorson, T.B., 1971. Movement of bull sharks, Carcharhinus leucas, between Caribbean Sea and Lake Nicaragua demonstrated by tagging. Copeia, 1971, 336-338.

Wilson, G.D. \& Boehlert, G.W., 2004. Interaction of ocean currents and resident micronekton at a seamount in central North Pacific. Fournal of Marine Systems, 50, 39-60.

Submitted 2 March 2005. Accepted 9 August 2005. 